\title{
Amistats perilloses \\ La recepció de la Crítica de la facultat de jutjar per part de C. Greenberg
}

\author{
Pol Capdevila
}

L'apropiació que fa Clement Greenberg de la Crítica de la facultat de jutjar des dels anys quaranta en endavant ha ajudat a difondre una lectura de l'estètica kantiana parcial i en alguns aspectes injusta; no només això, darrere una tal perspectiva interpretativa, de caire formalista, hi subjau una concepció de l'estètica que, segons el meu entendre, es pot definir com a antikantiana. Resumiré, primer, els principis estètics bàsics de Greenberg i, segon, els contrastaré amb els de Kant. ${ }^{1}$

Clement Greenberg, crític d'art novaiorquès, va defensar, al llarg de la seva carrera, que el judici estètic es basa exclusivament en el sentiment de plaer o desplaer, d'atracció o rebuig que una obra provoca en l'espectador. Fent-se acompanyar habitualment de l'autoritat kantiana, Greenberg explica que el judici estètic és sobretot un acte d'avaluació en termes binaris de "sí o no», "de més o menys satisfacció», basat en l'única referència del sentiment de gust o disgust. $^{2}$ El judici és una intuïció espontània que no té cap suport racional, perquè la seva font és totalment sensible — segons ell, tal com el terme estètic indica. "Nobody has yet been able so show [...] anything of essential quality in any kind of art that called on one's reasoning powers for either it's appreciation or its creation. (I'm not alone in maintaining this. Kant and Croce say the same in essence)». ${ }^{3}$

Per això, també com Kant, Greenberg s'oposa a qualsevol judici estètic que pretengui descansar en demostracions, en proves o, en el seu defecte, en qualsevol explicació de caire racional. ${ }^{4}$ No obstant això, el judici estètic no esdevé un judici amb valor simplement subjectiu, sinó que, al contrari, posseeix una

1. Greenberg feia sovint referència a les seves idees estètiques en les seves crítiques, les quals es troben a The Collected Essays and Criticism I-IV, The University of Chicago Press, 1986, que citaré també amb el títol de l'article, l’any de publicació, el número del volum i el de la pàgina. Cap al final de la seva carrera, va publicar en articles els resultats d'una sèrie de conferències on va condensar la seva concepció de l'estètica. Tot aquest material es troba recollit a Homemade Aesthetics, Oxford Univesity Press, 1999, que citaré pel títol i la pàgina.

2. Homemade Aesthetics, p. 7.

3. "Review of "Andrea del Sarto" by S. J. Freedberg", 1964, IV, 201.

4. Homemade Aesthetics, p. 12 s.; també a «Avantgarde and Kitsch», I, 1939, p. 34. 
validesa general. De fet, argumenta Greenberg, està demostrat que, a la llarga, tots aquells que dediquen força temps a gaudir de l'art acaben posant-se d'acord almenys en quines obres cal considerar com les més reeixides. ${ }^{5}$ L'experiència, diu, mostra que hi ha un acord mutu entre nosaltres.

Per a Greenberg, el fet que el judici de gust es basi exclusivament en la intuïció sensible significa que l'essència de les diverses arts rau en la seva part material, en els seus elements i mitjans sensibles. Els elements conceptuals o els continguts narratius o representatius, quan n'hi ha, llavors són secundaris o accidentals a l'hora de jutjar una obra; millor dit, el contingut del judici consisteix en l'efecte que produeix el mitjà artístic o la "forma» de l'obra en l'espectador. ${ }^{6}$ La pintura, per exemple, és purament visual i en dues dimensions, utilitza la línia i el color i els seus materials consisteixen principalment en la pintura i el llenç —o altres suports—; és per això que l'experiència estètica d'una obra pictòrica consisteix a "passejar-hi la mirada".

Amb aquestes breus pinzellades teòriques, es pot entendre per què Greenberg és conegut com un dels grans defensors de Pollock — no ens passa sovint que els nostres gustos defineixen part dels nostres principis teòrics? - l'expressionisme abstracte i d'altres tendències artístiques que protagonitzen la seva activitat en l'explicitació del mitjà artístic. Amb el mateix esquema s'explica la seva visió de la història de l'art modern. Segons ell, l'evolució de l'art consisteix en una presa de consciència de les seves tècniques i en una purificació de la forma. ${ }^{7}$ A partir del Renaixement, època en què s'arriba a un dels màxims extrems de l'il.lusionisme i de la dissimulació dels mitjans artístics, l'art pictòric va alliberant-se del domini de la representació, pren progressivament consciència de la seva forma, purament sensible, i per això es dirigeix cap a l'abstracció i cap a la manifestació d'aquella painterliness — terme encunyat en el barroc alemany (malerisch) i que ell utilitzava sovint-. En la mateixa línia, per exemple, es va permetre jutjar sorprenentment el surrealisme com un estil reaccionari, atès que un dels seus principis és la «representació» de l'inconscient, quan en aquell moment altres avantguardes ja prescindien de la figuració. ${ }^{8}$

Malgrat l'aparent coincidència entre Greenberg i Kant en la defensa d'un judici estètic fonamentat en el sentiment de plaer o desplaer i el rebuig de la interferència de qualsevol regla o principi conceptual, hi ha diverses raons per rebutjar aquesta pretesa afinitat.

Que el judici de gust es fonamenti en el sentiment, en cap cas significa per a Kant que l'experiència estètica romangui en l'àmbit de la intuïció. Per al filòsof, els judicis d'aquesta mena són judicis sobre sensacions agradables

5. Homemade Aesthetics, p. $46 \mathrm{~s}$.

6. Homemade Aesthetics, p. $70 \mathrm{~s}$.

7. "Review of the Exhibition A Problem for Critics", I, 1945, p. 29.

8. "Avantgarde and Kitsch», I, 1939, p. 9. 
- com la que proporciona el menjar-, en les quals no hi té cap paper la vessant intel.lectual humana (Critica de la facultat de jutjar, $\$ 1-3$ ). En el judici estètic, hi participa indefectiblement l'enteniment en general, que permet la síntesi de la sensibilitat en una experiència — en sentit propi- i la dota d'un caràcter reflexiu. Aquest moviment reflexiu de les capacitats no és només inherent a l'experiència estètica; el gaudi estètic consisteix precisament en l'autoreflexió de les facultats cognoscitives. En efecte, les facultats suspenen la determinació conceptual sobre l'objecte construint una idea estètica —una espècie de símbol— ${ }^{9}$, i és en aquest procés que senten que són aptes per conèixer el món del qual tant l'objecte com el subjecte cognoscitiu formen part (ibídem $\$ 9-12$ ).

Per a Greenberg, només hi ha reflexió en el moment en què l'artista es qüestiona l'essència de l'art i de la producció. Greenberg no sembla reconèixer la important vessant creativa de la seva pròpia feina, que forma part del mateix acte de judicar estèticament. Reduint el judici estètic a un declaració de plaer subjectiu, tampoc no admet l'aspecte d'aquest que potser més fascinava Kant - i que va ser una de les seves fites, malgrat que hagi estat quasi sempre passada per alt: es tracta precisament de la introducció de l'element de la convenció social en un judici autònom, el qual, per tant, només pot explicar-se en el seu exercici públic i que, aquí rau el més important, fonamenta l'espai intersubjectiu entre els receptors, l'espai de comunicació social. ${ }^{10}$

Aquesta diferència entre Greenberg i Kant és el que fa que, mentre que per al crític d'art només és possible constatar en la vida pràctica un cert acord en els judicis, per al crític transcendental és exactament el contrari. Per a Kant, fins i tot en el cas que el meu judici estètic davant d'una obra diferís del de tots els altres, això no hauria pas de fer-me dubtar del meu sentiment estètic.

Per aquestes raons, la simplificació de la lectura formalista de Greenberg sobre l'estètica kantiana no permet comprendre aquesta fantàstica capacitat del judici estètic de fomentar l'autonomia del subjecte, l'entesa entre les persones, la comunicació de valors sobre el món i la diversitat d'opinions que Kant va defensar. De manera similar, també Gadamer va criticar, de la tercera Crítica kantiana —injustament, ja ho veiem-, la llavor d'aquesta mal anomenada «estetització de la mirada». ${ }^{11}$

9. La idea estètica, indefinible per qualsevol concepte o discurs, s'sassembla al símbol en què posseeix alhora una vessant sensible i una vessant intel-lectual irreductibles l'una a l'altra (vegeu especialment ibídem $\$ 49$ ). En la meva tesi doctoral, intento exposar-hi que les idees estètiques mostren perspectives cognitives sobre el món.

10. Vegeu J. Jaques, "Introducció», a Critica de la facultat de jutjar, Edicions 62, Barcelona, 2004.

11. Vegeu les pàgines 43-48 de Wahrheit und Methode (p. 73, 75 y s. de l'edició castellana a Ediciones Sígueme) i els capítols del primer volum, I part, I.1.2. «Subjetivización de la estética por la crítica kantiana». 